\title{
Assessment of Radon Concentration within Construction Materials Used in Wolaita Sodo, Ethiopia
}

\author{
Nigus Maregu Demewoz \\ Departments of Physics, College of Natural and Computational Science, Wolaita Sodo University, Wolaita Sodo, Ethiopia \\ Email address: \\ nigusmaregu@gmail.com

\section{To cite this article:} \\ Nigus Maregu Demewoz. Assessment of Radon Concentration within Construction Materials Used in Wolaita Sodo, Ethiopia. Radiation \\ Science and Technology. Vol. 3, No. 5, 2017, pp. 41-46. doi: 10.11648/j.rst.20170305.11
}

Received: August 8, 2017; Accepted: September 15, 2017; Published: October 10, 2017

\begin{abstract}
The inhalation of radon decay products is the second most leading reasons for lung cancer after smoking. Building materials are an important source of indoor radon. This article describes the determination of the exhalation rate of radon from construction materials by the use of commercially available digital radon measuring device. Six types of construction materials were collected from the study area; these are cement, metal, sand, rock, clay brisk and gypsum. The measurements of effective radium content and radon concentration in those materials were investigated. The concentration was measured by alpha spectroscopy detection technique with Corentium digital radon detector. It was found that the overall average radon concentration in the construction materials varied from $58.46 \mathrm{~Bq} / \mathrm{m}^{3}$ to $307.84 \mathrm{~Bq} / \mathrm{m}^{3}$, which is above the recommended action level. The average effective radium content varies from $69.85 \mathrm{~Bq} / \mathrm{kg}$ to $367.79 \mathrm{~Bq} / \mathrm{kg}$ which is below the maximum permissible value of $370 \mathrm{~Bq} / \mathrm{kg}$ as recommended by Organization for Economic Corporation and Development (OECD) but it is near to maximum, so it can pose significant threat to the population. The average annual effective inhalation dose varied from $0.53 \mathrm{mSv} / \mathrm{yto} 2.77 \mathrm{mSv} / \mathrm{y}$. The mean excess lung cancer risk estimated by this work was found to range from $1.17 \%$ to $6.16 \%$ within average value of $2.92 \%$. The average of Excess Lifetime Cancer Risk (ELCR) is greater than with the estimated risk of $1.3 \%$ due to a radon exposure of $148 \mathrm{Bqm}^{-3}$ which is the action level of Environmental protection agency (EPA). The mass exhalation rates of radon vary from $14.98 \times 10^{-6}$ to $97.91 \times 10^{-6} \mathrm{~Bq} \cdot \mathrm{kg}^{-1} \cdot \mathrm{d}^{-1}$ with a mean value of $57.91 \times 10^{-6}$ $\mathrm{Bq} \cdot \mathrm{kg}^{-1} \cdot \mathrm{d}^{-1}$. The surface exhalation rates of radon have been found to vary from $23.85 \times 10^{-5}$ to $155.91 \times 10^{-5} \mathrm{~Bq} \cdot \mathrm{kg}^{-1} \cdot \mathrm{d}^{-1}$ with a mean value of $91.46 \times 10^{-5} \mathrm{~Bq} \cdot \mathrm{kg}^{-1} \cdot \mathrm{d}^{-1}$. This indicates the contributions of construction materials in the indoor radon are very high.
\end{abstract}

Keywords: Effective Radium Content, Radon Exhalation Rates, Inhalation dose, Life Fatality Risk, Corentium Radon Detector

\section{Introduction}

Human being is continuously exposed to ionizing radiation from naturally occurring radioactive elements. The origin of these materials is the earth's crust, but they find their way into building materials, air, water, food and the human body itself (UNSCEAR, 2000). In many parts of the world, building materials containing radioactive material have been used for generations. As individuals spend more than $80 \%$ of their time indoors, the internal and external radiation exposure from building materials creates prolonged exposure situations (ICRP 1999). One of the most abundant radioactive elements in the earth's crust is radon which is found in uranium ores, phosphate rock, and shale's, igneous and metamorphic rocks such as granite, gneiss, and schist, and to a lesser degree, in common rocks such as limestone and in construction materials (Ael Taher., 2011). Since thorium and uranium are two of the most common natural radioactive elements on earth, since their isotopes have very long halflives, on the order of billions of years, radon will be present in nature long into the future in spite of its short half-life as it is continually being regenerated (Mark Baskaran, 2016; Who, 2009).

According to Mohd Zubair et al., 2011 unlike all the other intermediate elements in the aforementioned decay chains, radon is, under normal conditions, gaseous and easily inhaled and it causes health hazard. It is often the single largest contributor to an individual's background radiation dose, but due to local differences in geology, the level of the radon-gas 
hazard differs from location to location (WHO, 2009). Despite its short lifetime, radon gas from natural sources can accumulate in buildings, especially, due to its high density, in low areas such as basements and crawl spaces. Radon can also occur in ground water for example, in some spring waters and hot springs. Unlike the gaseous radon itself, radon daughters are solids and stick to surfaces, such as dust particles in the air and simply inhaled and getting through the food chain and may cause cancer ( Nigus M. et al.., 2015, Abdalsattar k. et al., 2015). Radon mostly enters a building directly from the soil through the lowest level in the building that is in contact with the ground. High levels of radon in the water supply can also increase indoor radon air levels. Typical entry points of radon into buildings are cracks in solid foundations, construction joints, cracks in walls, gaps in suspended floors, gaps around service pipes, cavities inside walls, and the water supply (Ael Taher., 2011 and Anil Sharma et al., 2014). Epidemiological studies have shown a clear link between breathing high concentrations of radon and incidence of lung cancer. It is the second leading cause of lung cancer next to cigarette. It also causes intestinal, abdominal and skin cancer. Radon is a contaminant that affects indoor air quality worldwide (UNSCEAR, 2000; EPA, 2003; Nigus M. 2015)

As the main sources of radiation are naturally occurring radioactive materials, the eradication of cancer is growing up worldwide. Investigation and mitigation of radionuclide is one of the most suitable ways to reduce the growing up of cancer. Most of the persons are spent their time in the home and office, this implies that the construction materials have its own contribution to the emanation of radon. Such studies are not done in the study area that is why we concern on the most abundant radioactive gas and its health impact to the population.

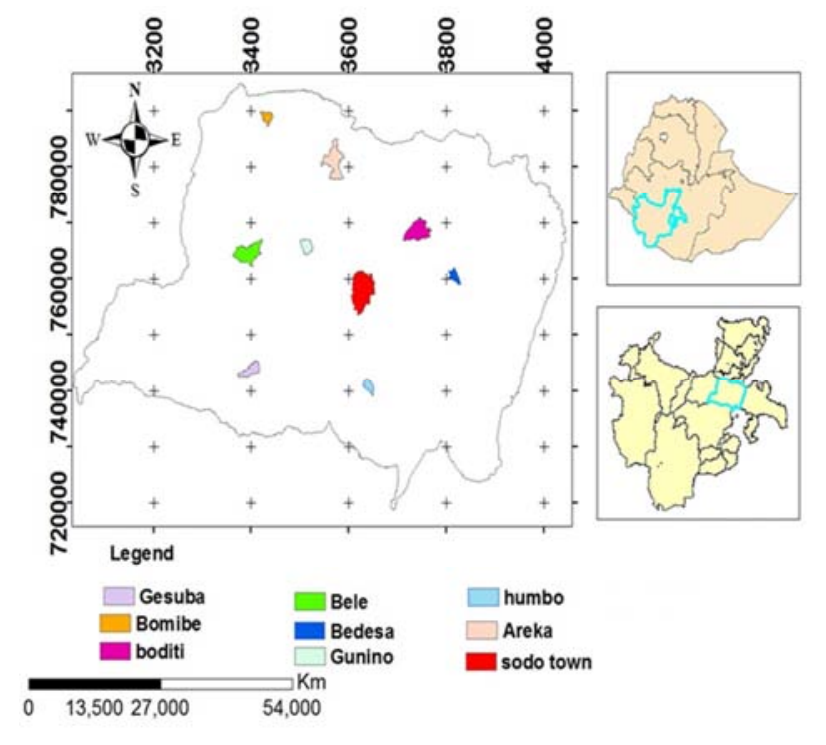

Figure 1. Map of wolaita Sodo zone, Ethiopia.

\section{The Study Area}

Wolaita is a Zone in the Ethiopian Southern Nations,
Nationalities, and Peoples' Region (SNNPR) and the administrative center of Wolayita is Sodo. It has a latitude and longitude of $6^{\circ} 54^{\prime} \mathrm{N} 37^{\circ} 45^{\prime} \mathrm{E}$. According to the most recent census (2007), the people of Wolayta number 1.7 million, or 2.31 percent of the country's population, of whom 289,707 are city dwellers.

\section{Materials and Methods}

Experimental method for radium and radon detection is based on alpha particle counting of radon. Alpha spectroscopy detection method with the help of Corentium digital radon detector was used for the measurements of radon in the construction materials of Wolaita Sodo, Ethiopia (Nigus M. et al 2017). Sixteen building material samples were collected from wolaita Sodo town construction sites. The samples are grouped in to six types; those are cement, metal, sand, rock, clay brisk and gypsum. These samples were dried in oven, milled, crushed, sieved by $2.5 \mathrm{~mm}$ mesh in order to get fine quality of the samples, $50 \mathrm{gm}$ of each sample was placed inside a plastic cylindrical container a period of four weeks in order to get equilibrium between radium and radon, placed Corentium digital radon detector in to sample for a period of one day. The detector can count all the tracks of alpha particles in the volume of the cane. The radiological effects of radon from construction materials were calculated according to the following equations.

\section{Mathematical Equations}

Once the radioactive equilibrium is established, one may use the radon alpha analysis for the determination of steadystate activity of radium. The activity of radon will increase with time $\mathrm{T}$ after closing of the cylindrical can, according to the relation:

$T_{e}$ is the effective exposure time which is related with the actual exposure time $\mathrm{T}$ and decay constant $\lambda_{\mathrm{Rn}}$ for ${ }^{222} \mathrm{Rn}$ with the relation (Nigus M. et al., 2015 and Anil Sharma et al., 2014).

$$
T_{e}=\left[T \lambda_{R n}^{-1}\left(1-e^{-\lambda_{R n} T}\right)\right]
$$

The effective radium content of the sample can be calculated by using the relation (Nigus M. et al., 2015; Shar A. 2015; Sintie W. et al 2013).

$$
C_{R n} C_{R a}\left(1-e^{-\lambda_{R n} T}\right)
$$

The mass exhalation rate of the sample for release of radon can be calculated by using the expression (Sintie W. et al 2013)

$$
E_{x}(M)\left(B q \cdot K g^{-1} d^{-1}\right)=C_{R a}\left(\frac{\lambda_{R a}}{\lambda_{R n}}\right)\left(\frac{1}{T}\right)
$$

The surface exhalation rate of the sample for release of radon can be calculated by using the expression (Sintie W. et al 2013; Nigus M. et al 2015 and Anil Sharma et al., 2014).

$$
E_{x}(S)\left(B q \cdot m^{-1} d^{-1}\right)=C_{R a}\left(\frac{\lambda_{R a}}{\lambda_{R n}}\right)\left(\frac{1}{T_{e}}\right)\left(\frac{M}{A}\right)=E_{x}(M)\left(\frac{M}{A}\right)
$$

Where $\mathrm{M}$ is the mass of the sample in $\mathrm{kg}$, $\mathrm{A}$ is the area of the cross section of the cylindrical can in $\mathrm{m}^{2}$ and $\mathrm{h}$ is the 
distance between the detector and top of the soil sample in meter.

The inhalation dose of alpha particle emitted from radium and attached to the aerosols was calculated in (mSv.y-1) using the relation: (Nigus M., 2017).

$$
D_{\text {in }}\left(\frac{S v}{y}\right)=n C_{R n}=0.009 C_{R n}
$$

Where $\lambda_{\mathrm{Ra}}$ is the decay constant for radium $\left({ }^{226} \mathrm{Ra}\right)$ and $\lambda_{\mathrm{Rn}}$ is the decay constant for radon $\left({ }^{222} \mathrm{Rn}\right)$.

The excess lifetime cancer risk (ELCR) due to radon gas is calculated by using equation (6) (Nigus Maregu et al.., 2017).

$$
E L C R=D_{i} \times T \times F_{R}
$$

Where $D_{i}$ - Exposure of radon, T - Average life time expectancy of the country (62.25 for Ethiopia), $F_{R}$ - Risk coefficient factor for exposure to radon in equilibrium and its progeny, Based on ICRP $F_{R}=5 \times 10^{-4}$ per Working Level Month $(\mathrm{WLM})=0.0357 \mathrm{~Bq} / \mathrm{m}^{3}$. Alpha index explains that when activity concentrations of radium in building materials exceed the value of $200 \mathrm{~Bq} \mathrm{~kg}^{-1}$, indoor radon could exceed $200 \mathrm{~Bq} \mathrm{~m}^{-3}$, due to radon exhalation from construction materials (Mohammed Ali et al.., 2011 and L. Fior et al.., 2012),

$$
\mathrm{I}_{\alpha}=\frac{\mathrm{C}_{\mathrm{Ra}}}{200 \mathrm{~Bq} \mathrm{Kg}^{-1}}
$$

\section{Result and Discussion}

The long term average and short term average radon concentration and other parameters are discussed in detail in

\begin{tabular}{|c|c|c|c|c|c|c|c|c|}
\hline \multirow[b]{2}{*}{ S. No. } & \multirow{2}{*}{$\begin{array}{l}\text { Sample } \\
\text { code }\end{array}$} & \multirow{2}{*}{$\begin{array}{l}\text { Long Term } \\
\text { Average Radon } \\
\left(\text { Bq. } \mathbf{m}^{-3}\right)\end{array}$} & \multirow{2}{*}{$\begin{array}{l}\text { Effective radium } \\
\text { content }\left(\mathrm{Bq} \cdot \mathrm{kg}^{-1}\right)\end{array}$} & \multirow{2}{*}{$\begin{array}{l}\text { Inhalation Dose } \\
D_{\text {in }}(\mathrm{mSv} / \mathrm{y}) \text { of } \\
\text { radon }\end{array}$} & \multirow{2}{*}{$\begin{array}{l}\text { Alpha } \\
\text { index } \mathbf{I}_{\alpha}\end{array}$} & \multirow{2}{*}{$\begin{array}{l}\text { excess lifetime } \\
\text { cancer risk\% }\end{array}$} & \multicolumn{2}{|l|}{ Exhalationrates } \\
\hline & & & & & & & 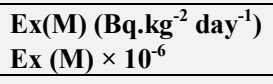 & $\begin{array}{l}\operatorname{Ex}(\mathrm{S})\left(\mathrm{Bq} \cdot \mathrm{m}^{-2} \mathrm{day}^{-1}\right) \\
\operatorname{Ex}(\mathrm{S}) \times 10^{-5} \\
\end{array}$ \\
\hline 1 & $\mathrm{C}-01$ & 82.88 & 99.02 & 0.75 & 0.41 & 1.67 & 33.00 & 52.55 \\
\hline 2 & $\mathrm{C}-02$ & 49.95 & 59.68 & 0.45 & 0.25 & 1.00 & 19.89 & 31.67 \\
\hline 3 & $\mathrm{C}-03$ & 86.95 & 103.88 & 0.78 & 0.43 & 1.73 & 34.62 & 55.13 \\
\hline 4 & $\mathrm{C}-04$ & 93.61 & 111.84 & 0.84 & 0.47 & 1.87 & 37.28 & 59.37 \\
\hline 5 & $\mathrm{G}-05$ & 72.15 & 86.20 & 0.65 & 0.36 & 1.44 & 28.73 & 45.75 \\
\hline 6 & M-06 & 74.74 & 89.30 & 0.67 & 0.37 & 1.49 & 29.76 & 47.39 \\
\hline 7 & $\mathrm{M}-07$ & 87.32 & 104.33 & 0.79 & 0.44 & 1.76 & 34.77 & 55.37 \\
\hline 8 & S-08 & 165.76 & 198.04 & 1.49 & 0.83 & 3.31 & 66.00 & 105.10 \\
\hline 9 & B-09 & 156.51 & 186.99 & 1.41 & 0.78 & 3.13 & 62.32 & 99.24 \\
\hline 10 & S-10 & 219.41 & 262.14 & 1.97 & 1.10 & 4.38 & 87.37 & 139.13 \\
\hline 11 & B-11 & 236.06 & 282.03 & 2.12 & 1.18 & 4.71 & 94.00 & 149.69 \\
\hline 12 & $\mathrm{~S}-12$ & 264.55 & 316.07 & 2.38 & 1.32 & 5.29 & 105.35 & 167.76 \\
\hline 13 & S-13 & 307.84 & 367.79 & 2.77 & 1.54 & 6.16 & 122.58 & 195.20 \\
\hline 14 & G-14 & 72.89 & 87.08 & 0.66 & 0.36 & 1.47 & 29.02 & 46.21 \\
\hline 15 & $\mathrm{R}-15$ & 120.25 & 143.67 & 1.08 & 0.60 & 2.40 & 47.89 & 76.26 \\
\hline 16 & $\mathrm{R}-16$ & 105.45 & 125.99 & 0.95 & 0.53 & 2.11 & 41.99 & 66.87 \\
\hline \multicolumn{2}{|c|}{ Average } & 140.6 & 164.00 & 1.27 & 0.70 & 2.82 & 54.66 & 87.04 \\
\hline \multicolumn{2}{|c|}{ Maximum } & 307.84 & 367.79 & 2.77 & 1.54 & 6.16 & 122.58 & 195.2 \\
\hline \multicolumn{2}{|c|}{ Minimum } & 49.95 & 59.68 & 0.45 & 0.25 & 1 & 19.89 & 31.67 \\
\hline
\end{tabular}
the tables below.

Table 1. Long Term Radon Concentration and its internal dose, Excess Lifetime Cancer Risk, Working Level and Alpha Index.

In the this study, we have measured the long and short term average evalues of rado nlevels in some construction materials collected from Wolaita Sodo, Ethiopia. We observed that the long term radon concentration varied from $49.95 \mathrm{~Bq} / \mathrm{m}^{3}$ to $307.84 \mathrm{~Bq} / \mathrm{m}^{3}$ with an average value of $140.6 \mathrm{~Bq} / \mathrm{m}^{3}$ and the short term radon concentration is varied from $66.97 \mathrm{~Bq} / \mathrm{m}^{3}$ to $307.84 \mathrm{~Bq} / \mathrm{m}^{3}$ with an average value of $151.21 \mathrm{~Bq} / \mathrm{m}^{3}$. The overall average radon concentration is varied from $145.91 \mathrm{~Bq} / \mathrm{m}^{3}$ to $172.33 \mathrm{~Bq} / \mathrm{m}^{3}$. The variation is due to different nature of construction materials. The maximum values were found in sand samples. For the inhalation part, we have known that the dissolved radon is a source of indoor radon, and its contribution would depend on the radon concentration, usage rate, the volume of the indoor environment and the air exchange rate. We observe that the overall average radon concentration is greater than the recommended value of $148 \mathrm{Bqm}^{-3}$ which is the action level of Environmental protection agency (EPA, 2003). 
Table 2. Short Term Radon Concentration and its Internal dose, Excess Lifetime Cancer Risk, Working Level and Alpha Index.

\begin{tabular}{|c|c|c|c|c|c|c|c|c|}
\hline \multirow[b]{2}{*}{ S. No. } & \multirow[b]{2}{*}{ Sample code } & \multirow{2}{*}{$\begin{array}{l}\text { Short Term } \\
\text { Average Radon } \\
\text { (Bq.m-3) }\end{array}$} & \multirow[b]{2}{*}{$\begin{array}{l}\text { Effective radium } \\
\text { content }\left(\mathrm{Bq} \cdot \mathrm{kg}^{-1}\right)\end{array}$} & \multirow{2}{*}{$\begin{array}{l}\text { Inhalation } \\
\text { Dose Din } \\
(\mathrm{mSv} / \mathrm{y})\end{array}$} & \multirow[b]{2}{*}{$\begin{array}{l}\text { Alpha index } \\
\text { Ia }\end{array}$} & \multirow[b]{2}{*}{$\begin{array}{l}\text { excess lifetime } \\
\text { cancer risk\% }\end{array}$} & \multicolumn{2}{|l|}{ Exhalationrates } \\
\hline & & & & & & & $\begin{array}{l}\operatorname{Ex}(M)(B q \cdot k g- \\
\left.{ }^{2} d^{-1}\right) \operatorname{Ex}(M) \times 10^{-6}\end{array}$ & $\begin{array}{l}\operatorname{Ex}(\mathrm{S})\left(\mathrm{Bq}_{\mathrm{m}} \mathrm{m}^{-2} \mathrm{day}^{-1}\right) \\
\operatorname{Ex}(\mathrm{S}) \times 10-5\end{array}$ \\
\hline 1 & $\mathrm{C}-01$ & 86.95 & 103.88 & 0.78 & 0.43 & 1.73 & 34.62 & 55.13 \\
\hline 2 & $\mathrm{C}-02$ & 81.4 & 97.25 & 0.73 & 0.41 & 1.62 & 32.41 & 51.61 \\
\hline 3 & $\mathrm{C}-03$ & 86.95 & 103.88 & 0.78 & 0.43 & 1.73 & 34.62 & 55.13 \\
\hline 4 & $\mathrm{C}-04$ & 106.93 & 127.75 & 0.96 & 0.53 & 2.13 & 42.58 & 67.8 \\
\hline 5 & $\mathrm{G}-05$ & 81.4 & 97.25 & 0.73 & 0.41 & 1.62 & 32.41 & 51.61 \\
\hline 6 & $\mathrm{M}-06$ & 74.74 & 89.30 & 0.67 & 0.37 & 1.49 & 29.76 & 47.39 \\
\hline 7 & $\mathrm{M}-07$ & 86.58 & 103.44 & 0.78 & 0.43 & 1.73 & 34.48 & 54.91 \\
\hline 8 & $\mathrm{~S}-08$ & 183.89 & 219.70 & 1.66 & 0.92 & 3.69 & 73.23 & 116.61 \\
\hline 9 & B-09 & 181.67 & 217.05 & 1.64 & 0.91 & 3.64 & 72.34 & 115.19 \\
\hline 10 & S-10 & 252.71 & 301.92 & 2.27 & 1.26 & 5.04 & 10.06 & 16.02 \\
\hline 11 & B-11 & 267.51 & 319.61 & 2.41 & 1.34 & 5.36 & 10.65 & 16.96 \\
\hline 12 & $\mathrm{~S}-12$ & 271.95 & 324.91 & 2.45 & 1.36 & 5.44 & 10.83 & 17.25 \\
\hline 13 & S-13 & 307.84 & 367.79 & 2.77 & 1.54 & 6.16 & 12.26 & 19.52 \\
\hline 14 & $\mathrm{G}-14$ & 66.97 & 80.01 & 0.60 & 0.33 & 1.33 & 26.67 & 42.47 \\
\hline 15 & $\mathrm{R}-15$ & 148.37 & 177.26 & 1.34 & 0.74 & 2.98 & 59.08 & 94.08 \\
\hline 16 & $\mathrm{R}-16$ & 133.57 & 159.58 & 1.20 & 0.67 & 2.67 & 53.19 & 84.7 \\
\hline \multicolumn{2}{|c|}{ Average } & 151.21 & 180.66 & 1.36 & 0.76 & 3.02 & 60.21 & 95.88 \\
\hline \multicolumn{2}{|c|}{ Maximum } & 307.84 & 367.79 & 2.77 & 1.54 & 6.16 & 73.23 & 116.61 \\
\hline \multicolumn{2}{|c|}{ Minimum } & 66.97 & 80.01 & 0.6 & 0.33 & 1.33 & 10.06 & 16.02 \\
\hline
\end{tabular}

Note that from table (1) and (2): Cement (C), Gypsum (G), Meta (M), Sand (S), Brisk (B) and Rock (R).

The average value of inhalation dose is $1.27 \mathrm{mSv} / \mathrm{y}$ and $1.36 \mathrm{mSv} / \mathrm{y}$ in long term and short term radon concentration respectively, with in a total average value of $1.32 \mathrm{mSv} / \mathrm{y}$. The mean excess lung cancer risk estimated by this work was found to range from $2.82 \%$ to $3.82 \%$ within average value of $2.92 \%$, which is greater than the estimated risk of $1.3 \%$ (13 deaths in 1000 peoples) due to a radon exposure of $148 \mathrm{Bqm}^{-3}$ which is the action level of Environmental protection agency (EPA, 2003). The study area needs more investigation on radon concentration in soil, water and building materials. The result indicates that the place needs caution in order to minimize the concentration. We observe that the values of radium content and radon exhalation rates in soil samples are different at different construction materials; this is due to the nature of the materials. Radon flux density (i.e., ${ }^{222} \mathrm{Rn}$ exhalation rate) depends upon a number of parameters that behave in a stochastic and independent fashion, such as the radioactive disintegration of ${ }^{226} \mathrm{Ra}$ to produce radon, the direction of recoil of radon in the grain, the interstitial soil moisture condition in the vicinity of ejected radon atom and its diffusion in the pore space (UNSCEAR 2000). We also observe that the value of long term average effective radium content in collected samples varied from 59.68 to 367.79 Bq. $\mathrm{kg}^{-1}$ with a mean value of $164.00 \mathrm{~Bq} \cdot \mathrm{kg}^{-1}$. And also the value of short term average effective radium content in collected samples vary from 80.01 to $367.79 \mathrm{~Bq} \cdot \mathrm{kg}^{-1}$ with a mean value of 180.66 Bq. $\mathrm{kg}^{-1}$. This implies that the short term average variation is greater than the long term (annual) average of radium content.

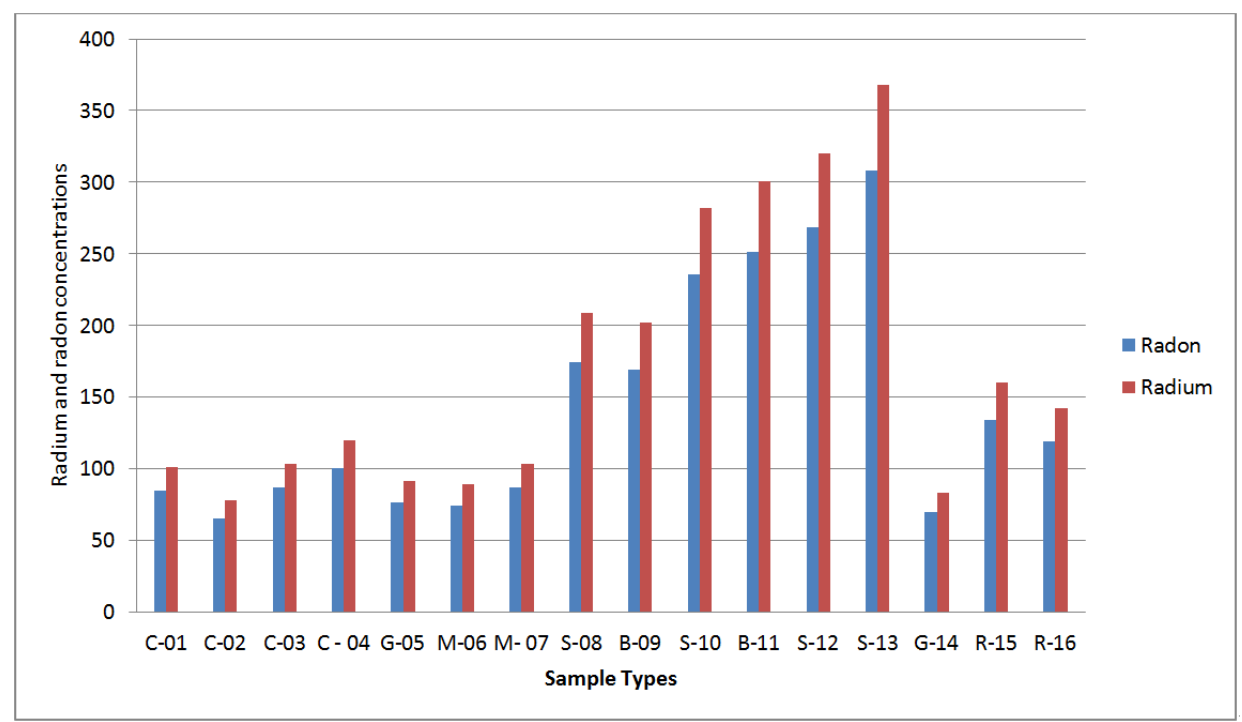

Figure 2. Average Effective Radium Content and Radon Concentrations with Different Types of Construction Materials. 


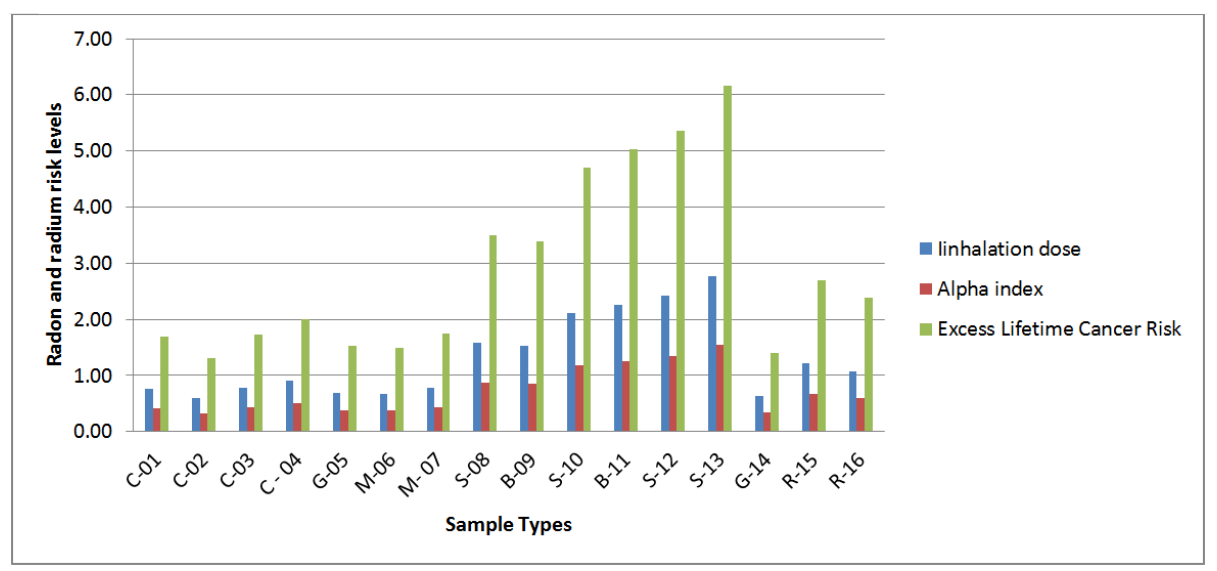

Figure 3. Description of the Average Radon Risk Level in Different Parameters for each Sample.

The overall average effective radium content varied from 69.85 to $367.79 \mathrm{~Bq} \cdot \mathrm{kg}^{-1}$. Among all samples sand samples have shown the highest values of effective radium content and radon concentration. This is may be due to the small pieces of different rocks and minerals that are mixed in to the sand, whereas small values have been shown in stone and cement samples.

It is also clear from the Table $1 \& 2$ that the long term average mass exhalation of radon varies from 19.89 to $122.58 \times 10^{-6} \mathrm{~Bq} \cdot \mathrm{kg}^{-1}$. day ${ }^{-1}$ with a mean value of $54.66 \times 10^{-6}$ Bq. $\mathrm{kg}^{-1}$.day ${ }^{-1}$, While the surface exhalation of radon varies from $31.67 \times 10^{-5}$ to $195.2 \times 10^{-5}$ Bq. $\mathrm{m}^{-2}$. day $^{-1}$ with a mean value of $87.04 \times 10^{-5}$ Bq. ${ }^{-2}$.day ${ }^{-1}$. The short term average mass exhalation of radon varies from 10.06 to $73.23 \times 10^{-6}$ Bq. $\mathrm{kg}^{-1} \cdot$ day $^{-1}$ with a mean value of $60.21 \times 10^{-6}$ Bq. $\mathrm{kg}^{-1}$.day ${ }^{-1}$, While the surface exhalation of radon varies from $16.02 \times 10^{-5}$ to $116.61 \times 10^{-5} \mathrm{~Bq} \cdot \mathrm{m}^{-2}$. day $^{-1}$ with a mean value of $95.88 \times 10^{-5}$ Bq. ${ }^{-2} \cdot$ day $^{-1}$. The overall mass and surface exhalation rates of radon gas varied from 14.975 to $97.905 \times 10^{-6} \mathrm{~Bq} \cdot \mathrm{kg}^{-1}$.day ${ }^{-1}$. Similarly the overall average surface exhalations of radon gas from construction materials varied from 23.845 to $155.91 \times 10^{-5} \mathrm{~Bq} \cdot \mathrm{kg}^{-1}$.day ${ }^{-1}$. This indicates that radon gas is emanated from construction materials and exhalants in to the atmosphere rapidly.

\section{Conclusion}

In the study area the overall arithmetic mean radon gas is higher than the recommended action level. The annual effective inhalation dose received by the residents in the study area is near to the limit of the recommended action level $(3-10 \mathrm{mSv})$. The average of Excess Lifetime Cancer Risk (ELCR) is greater than the estimated risk of $1.3 \%$ (13 deaths in 1000 peoples), due to a radon exposure of 148 $\mathrm{Bqm}^{-3}$ which is the action level of Environmental protection agency of America (EPA). We also observe that the short term average radon and radium concentrations are greater than the long term average, which are greater than the recommended values of EPA. Its value is larger in sand samples where as small in cement samples. The overall average value of radium content in the soil samples from these construction materials are found to be $172.33 \mathrm{~Bq} \cdot \mathrm{kg}^{-1}$, while the global average value of radium content in the earth crust is known to be $40 \mathrm{~Bq} \cdot \mathrm{kg}^{-1}$. The surface exhalation and mass exhalation rates of radon from these construction materials correspond to their radium contents. The exhalation of radon to the environment is fast. Generally the construction materials in the study area are not safe as far as the health concern due to the radium and radon concentration. It can pose different disease such as lung cancer, bone cancer, sores, lymphoma, kidney damage, born defects, cataracts teeth fracture and diseases that affect the formation of blood such as leukemia and anemia. We recommend that the people should use radon reducing techniques, such as; Sub slab depressurization, ventilation and installing sump system in order to protect ourselves from toxic radioactive gases.

\section{References}

[1] UNSCEAR. (2000). United Nations Scientific Committee on the Effects of Atomic Radiation. Sources and Effects of Ionizing Radiation. New York.

[2] International Commission on Radiological Protection (ICRP), (1999). Protection of the Public in Situations of Prolonged Radiation Exposure, Publication 82, Elsevier Science B. V.

[3] Ael Taher. (2011). Assessment of natural radioactivity levels and radiation hazards for building materials used in assim area, saudi Arabia, Journ. Phys., Vol. 57, Nos. 3-4, P. 726-735

[4] Mark Baskaran (2016), Radon: Atracer for geological, geophysical and geotechnical studies, ISBN 978-3-31921329-3, DOI 10.1007/978-3-319-213293

[5] WHO (World Health Organization). (2009). WHO hand book on indoor radon, ISBN 9789241547673.

[6] Mohd Zubair, M Shakir Khan Deepak Verma, (2011). Radium Studies in Sand Samples Collected from Sea Coast of Tirur, Kerala, India Using LR-115 Plastic Track Detectors; Int. J. Appl. Sci. Eng., 211 (9): 143.

[7] Nigus Maregu \& Bhardwaj M. K. (2015). Risk assessments of radium content and radon exhalation rates in soil samples of Shire Indaslassie area, Ethiopia, I. J. E. M. S., VOL.6 (3): 114-118. 
[8] Abdalsattar K. Hahim, Laith A. Najam. (2015). Concentrations, radium content and radon exhalation rate in Iraqian Building materials samples, International journals of physics (3), 159-164.

[9] Anil Sharma, Ajay Kumar Mahur, R. G. Sonkawade, A. C. Sharma, Raj Kumar and Rajendra Prasad. (2014). Radon exhalation in some building construction materials and effect of plastering and paints on the radon exhalation rate using fired bricks, Advances in Applied Science Research, 2014, 5(2): 382-386.

[10] EPA, (2003). Assessment of Risk from Radon in Homes (Washington, DC: Environmental Protection Agency) EPA 402-R03-003, USA.

[11] Sahar A. Amin. (2015 ) Measurements of radon exhalation rates in building materials used in Iraqi houses, Journal of Applied Sciences and Engineering Research, Vol. 4, Issue 4, 2 , 437-442.
[12] Sintie Welelaw \& Bhardwaj M. K., (2013). Assessment of hazards due to radon's mass and surface exhalation rates, and radium content in soil samples of Lalibela, Ethiopia, I. J. E. M. S., VOL. 4 (4): 445-448.

[13] Nigus Maregu. and Tilahun G. (2017). Indoor Radon Concentration and its Associated Health Effect in the Dwellings of Fiche Selale North Shewa, Ethiopia, Journal of Natural Sciences Research, 7 (7): 43-47.

[14] Hohhamed Ali, Aziz Ahmed Qureshi, Abdul Waheed, Muzahir Ali Baloch, Hamza Qayyum, Muhhamed Tufai, Hameed Ahmed Khan. (2011), Assesemments of radiological hazard of NORM in Margalla Hills limestone, Pakistan, Environ. Monit. Assess DOI 10.1007/s10661-0112290-5, Springer

[15] L. Fior J. Nicolosi Correa, S. A. Paschuk, V. V. Denyak, H. R. Schelin, B. R. Soreanu Pecequilo, J. Kappke,. (2012). Activity measurements of radon from construction materials, Applied radiation and isotopes (70), 1407-1410. 